\title{
ФОРМЫ ГОСУДАРСТВЕННОГО НАДЗОРА И КОНТРОЛЯ В СОЦИАЛЬНО-ЭКОНОМИЧЕСКОЙ СФЕРЕ
}

\author{
(C) 2020 Щукина Татьяна Владимировна \\ доктор юридических наук, доцент, ведущий научный сотрудник \\ Институт государства и права Российской академии наук, Россия, Москва \\ E-mail: shukina-tv@mail.ru
}

Предметом настоящей статьи выступает исследование новых форм государственного надзора и контроля в социально-экономической сфере, включая рассмотрение современной трансформации системы субъектов государственного управления. Тема статьи отражает сущность и характерные особенности изменения форм и методов управленческой деятельности государства, форм государственного надзора и контроля в социально-экономической сфере с точки зрения формирования инновационной инфраструктуры стратегического развития в Российской Федерации. Целью настоящей статьи являются выявление новой системы субъектов государственного управления и выявление зависимости от этого новизны форм государственного надзора и контроля в социальноэкономической сфере на современном этапе управления, места и роли социальной кооперации субъектов и объектов государственного управления в этом процессе. Методологию данной работы составили сравнительный, формально-юридический, аналитический методы. Результаты работы - это формулирование особенностей государственного надзора и контроля в социально-экономической сфере. Область применения результатов работы включает в себя систему публичного управления.

Ключевые слова: государственное управление в социально-экономической сфере, формы государственного надзора и контроля, социальная кооперация, новая система субъектов государственного управления

В настоящее время происходит расширение форм и методологии государственного управления. Это обусловлено структурными и содержательными изменениями объектов государственного управления. Укрепление позиций права частной собственности смоделировало новые формы взаимодействия объектов государственного управления и субъектов государственного управления, изменило сущность методов государственного управления и, соответственно, форм государственного надзора и контроля.

Широко реализуемое проектное управление в сфере национальных проектов и пилотных государственных программ усиливает значение метода проектного управления в системе государственного управления. Не утрачивает своей роли и программный метод как разновидность метода регулирования. Усиление роли функции оценки в системе публичного управления формирует важность оценочных процедур и соответственно метода оценки. Целью оценочных процедур является гармонизация взаимодействия объектов и субъектов публичного управления. Оценочные процедуры в деятельности органов исполнительной власти сопровождаются разработкой разнообразных рейтингов, сводов лучших практик, перечней, мониторингов [1], индексов и т.п. Подобная управленческая деятельность имеет аналитический, обобщающий характер, способствующий формированию реалистичного облика управления в соответствующей области и дальнейшему улучшению его качества и повышению эффективности. Оценку могут производить специально уполномоченные субъекты, профессиональные объединения и другие субъекты в соответствии с требованиями законодательства. Порядок и основания проведения официальных оценочных процедур закрепляется в нормативных правовых актах.

Трансформация сущности объектов государственного управления повлекла за собой серьезные изменения в структуре системы субъектов государственного управления. Формирование новой системы государственного управления обуславливает также непосредственную модернизацию форм государственного надзора и контроля, которые и осуществляют субъекты государственного управления. Рассмотрим харак- 
теристику системы субъектов государственного управления. Условно, по мнению автора, ее следует классифицировать на три уровня субъектов управления, где каждый уровень характеризуется определенной спецификой правового статуса и структуры субъектов управления.

Первый уровень субъектов государственного (публичного) управления - это федеральные органы исполнительной власти Российской Федерации и органы исполнительной власти субъектов Российской Федерации. Правительство Российской Федерации как коллегиальный высший орган государственной власти, возглавляющий единую систему исполнительной власти в Российской Федерации, обеспечивает реализацию внутренней и внешней политики Российской Федерации, включая государственное регулирование и стратегическое управление.

Иные федеральные органы исполнительной власти Российской Федерации также сохраняют стабильность основ административноправового статуса, хотя и в сочетании с регулярным изменением структуры системы федеральных органов исполнительной власти, некоторыми дополнениями в компетенцию отдельных федеральных органов исполнительной власти.

Основная трансформация административноправового статуса федеральных органов исполнительной власти Российской Федерации произошла в 2004 году согласно Указу Президента РФ от 9 марта 2004 г. № 314 «О системе и структуре федеральных органов исполнительной власти» [2]. Этим нормативным правовым актом была видоизменена система и компетенция федеральных органов исполнительной власти Российской Федерации. Подобная трансформация административно-правового статуса органа исполнительной власти обусловлена впервые документально закрепленной классификацией функций федерального органа исполнительной власти. В зависимости от содержания каждой группы функций федерального органа исполнительной власти определяется его компетенция, круг полномочий и вид федерального органа исполнительной власти.

Вышеупомянутый нормативный правовой акт установил четыре основных группы функций федерального органа исполнительной власти:

1) функции по принятию нормативных правовых актов. Основным федеральным органом исполнительной власти, осуществляющим подобные функции, выступает федеральное министерство. Федеральная служба и федеральное агентство реализуют функции нормативноправового регулирования в исключительных случаях,

2) функции по контролю и надзору. Основным федеральным органом исполнительной власти, обеспечивающим выполнение функций по надзору и контролю, является федеральная служба. Федеральное министерство и федеральная служба вправе реализовывать функции надзора и контроля в случаях, строго установленных указами Президента Российской Федерации или постановлениями Правительства Российской Федерации;

3) функции по управлению государственным имуществом. Исполнение подобных функций возложено на федеральное агентство. Федеральное министерство может выполнять указанные функции в исключительных случаях

4) функции по оказанию государственных услуг. Основным федеральным органом исполнительной власти, осуществляющим эти функции, выступает федеральное агентство. Федеральная служба по надзору не имеет права предоставлять платные услуги.

Указ Президента РФ от 9 марта 2004 г. № 314 «О системе и структуре федеральных органов исполнительной власти» закрепляет трехзвенную систему федеральных органов исполнительной власти, состоящую из федеральных министерств, федеральных служб и федеральных агентств. Обязательно каждый федеральный орган исполнительной власти в зависимости от группы исполняемых функций находится либо под руководством Президента Российской Федерации, либо - Правительства Российской Федерации. Общие основы компетенции федерального органа исполнительной власти также установлены в указе Президента Российской Федерации от 9 марта 2004 г. N 314 «О системе и структуре федеральных органов исполнительной власти». Федеральный орган исполнительной власти самостоятелен в осуществлении своих полномочий, установленных федеральными законами, актами Президента Российской Федерации и Правительства.

Органы исполнительной власти субъектов Российской Федерации. Федеральным законом от 6 октября 1999 г. № 184-ФЗ «Об общих принципах организации законодательных (пред- 
ставительных) и исполнительных органов государственной власти субъектов Российской Федерации» предусмотрены правовые основы системы органов государственной власти субъекта РФ.

Система органов исполнительной власти субъекта РФ включает в себя высший орган исполнительной власти субъекта РФ и иные органы исполнительной власти субъектов РФ. Под системой органов исполнительной власти субъекта РФ понимается совокупность организационно объединенных и находящихся во взаимной связи, различающихся правовым статусом и объемом полномочий органов исполнительной власти, иерархически связанных и взаимодействующих между собой. Законодательство субъектов РФ дает определения таким юридическим категориям, как исполнительный орган государственной власти субъекта РФ, структура органа исполнительной власти субъекта РФ, министерство субъекта РФ, инспекция субъекта РФ, управление субъекта РФ.

Под структурой исполнительных органов государственной власти субъекта РФ понимается перечень конкретных исполнительных органов, входящих в систему исполнительных органов государственной власти субъекта РФ и обеспечивающих реализацию высшим исполнительным органом государственной власти субъекта РФ возложенных на него задач и полномочий. Структура исполнительных органов государственной власти субъекта РФ определяется высшим должностным лицом субъекта РФ (руководителем высшего исполнительного органа государственной власти субъекта РФ) в соответствии с конституцией (уставом) субъекта РФ.

Относительно особенностей системы и структуры исполнительных органов государственной власти субъектов РФ отметим, что в субъектах РФ присутствует их разнообразие, различные классификации видов органов исполнительной власти, а также их функций.

Система органов исполнительной власти субъекта РФ утверждается, как правило, в законах субъектов РФ. Представим несколько ее вариантов, действующих в настоящее время. Первый из них включает в себя высший исполнительный орган государственной власти субъекта РФ, областные исполнительные органы, территориальные исполнительные органы [3]. Исполнительные органы государственной власти субъекта РФ делятся на областные и терри- ториальные исполнительные органы.

Областные исполнительные органы государственной власти создаются на основании решений Губернатора области, а порядок деятельности областных исполнительных органов государственной власти закрепляется в положении о соответствующем, органе, утвержденном Губернатором области или Правительством области.

В компетенцию областных исполнительных органов государственной власти входит:

- координация и руководство деятельностью территориальных исполнительных органов государственной власти, осуществляющих государственное управление в той же сфере;

- руководство народным хозяйством области, социальной сферой и охраной общественного порядка;

- управление подведомственными организациями;

- разработка и осуществление мероприятий по совершенствованию системы отраслевого и межотраслевого государственного управления;

- взаимодействие с федеральными органами исполнительной власти, органами местного самоуправления, территориальными исполнительными органами государственной власти области

- руководство и координация в сфере экономики, финансов, бюджета, управления государственной собственностью области, в сфере научно-технического прогресса, капитального строительства и материально-технического снабжения, в сфере труда, заработной платы и кадровой политики.

В этой же модели системы органов исполнительной власти субъекта РФ исполнительные органы государственной власти делятся на отраслевые и межотраслевые. Областные отраслевые исполнительные органы государственной власти области осуществляют государственное управление в одной из отраслей экономики либо социальной сферы на всей территории области. Областные межотраслевые исполнительные органы государственной власти осуществляют межотраслевое государственное управление. Подобная система органов исполнительной власти субъекта РФ действует в Алтайском крае, Республике Бурятия и других субъектах РФ.

Второй вариант [4] системы органов исполнительной власти субъекта РФ представляет собой совокупность: Правительства как высшего 
исполнительного органа государственной власти субъекта РФ, администрации Правительства области как органа исполнительной власти межотраслевой компетенции и иных исполнительных органов государственной власти субъекта РФ. К иным исполнительным органам государственной власти субъекта РФ относятся органы исполнительной власти отраслевой, межотраслевой и специальной компетенции, образуемые в форме самостоятельных государственных организаций, являющихся юридическими лицами, либо в форме государственных организаций, не имеющих такого статуса и функционирующих при Правительстве субъекта РФ. Органы исполнительной власти отраслевой и межотраслевой компетенции - это министерства, департаменты и управления. Органы исполнительной власти специальной компетенции - это службы и инспекции субъекта РФ.

Подобная система органов исполнительной власти субъекта РФ действует в Орловской области, Брянской области и других субъектах РФ.

Третий вариант системы органов исполнительной власти в субъекте Российской Федерации представлен более упрощенной схемой дифференцирования региональных органов управления. Это - высший исполнительный орган государственной власти субъекта РФ (администрация субъекта Российской Федерации) и исполнительные органы государственной власти субъекта Российской Федерации, образованные в форме департаментов, аппаратов, комитетов, управлений, инспекций.

Такая система органов исполнительной власти субъекта РФ действует в Томской, Липецкой областях и других субъектах РФ.

Второй уровень субъектов публичного управления, по мнению автора,- это квази-органы исполнительной власти. К ним относятся отдельные государственные корпорации, Центральный банк Российской Федерации и Пенсионный фонд Российской Федерации. Это связано с тем, что указанные публичные юридические лица выполняют государственные функции, которые согласно Указу Президента РФ от 9 марта 2004 г. № 314 «О системе и структуре федеральных органов исполнительной власти» реализуются исключительно федеральными органами исполнительной власти.

К государственным корпорациям, наделенным функциями федерального органа исполнительной власти, относятся: Роскосмос, Ростех,
Росатом. Автор считает, что это отраслевые публичные субъекты. Данные государственные корпорации имеют право разрабатывать и принимать:

- административные регламенты по предоставлению соответствующих государственных услуг и исполнению государственных функций;

- нормативные правовые акты в области стандартизации, государственного контроля и учета, выдачи сертификатов и разрешений;

- иные нормативные правовые акты в сфере своей деятельности за исключением случаев, предусмотренных Конституцией Российской Федерации, федеральными законами, указами Президента РФ, постановлениями Правительства РФ.

Государственные корпорации подобного вида наделяются некоторыми полномочиями и функциями органа государственного управления (например, в области обращения с радиоактивными отходами); осуществляют строительный надзор; обеспечивают реализацию государственной политики; принимают участие в законопроектной деятельности по вопросам, относящимся к установленной сфере деятельности, в порядке, установленном для федеральных органов исполнительной власти. Нормативные правовые акты, издаваемые государственной корпорацией в форме приказов, положений и инструкций, подлежат регистрации и опубликованию в порядке, установленном для федеральных органов исполнительной власти.

Своеобразен порядок создания и ликвидации государственных корпораций. Они создаются и ликвидируются на основании специального федерального закона, подлежат государственной регистрации. Государственные корпорации в соответствии со статьей 65.1. Гражданского кодекса создаются в организационно-правовой форме унитарного юридического лица. Правовой статус такого юридического лица носит неопределенный характер, так как не относится ни к учреждению, ни к некоммерческой унитарной организации, ни к унитарным предприятиям. Соотнести их к организационно-правовой форме публично-правовой компании также невозможно, потому что федеральным законом от 3 июля 2016 г. № 236-ФЗ «О публично-правовых компаниях в Российской Федерации и о внесении изменений в отдельные законодательные акты Российской Федерации» не предусмотрено преобразование пяти видов государственных 
корпораций в публично-правовые компании.

Правовой статус Центрального банка Российской Федерации (Банк России) является уникальным, и подобная особенность выделена в статье 48 Гражданского кодекса РФ. Банк России просто является юридическим лицом, без какой-либо дополнительной градации в части дифференциации организационно-правовой формы. Это обусловлено тем, что статус, цели деятельности, функции и полномочия Центрального банка Российской Федерации (Банка России) определяются Конституцией Российской Федерации и федеральными законами. Помимо разработки документов по предоставлению государственных услуг, приравненных к административным регламентам, Центральный банк Российской Федерации исполняет полномочия по разработке и проведению политики развития и обеспечения стабильности и функционирования финансового рынка Российской Федерации. Ранее данная функция выполнялась федеральным органом исполнительной власти (осуществление надзора и контроля, стандартизации).

Третий уровень субъектов публичного управления, по мнению автора, - это иные публичные юридические лица, осуществляющие переданные им государственные полномочия в целях реализации стратегических задач социально - экономического развития Российской Федерации. Или частно-публичные субъекты управления.

Данный уровень субъектов публичного управления не осуществляет нормативноправовое регулирование, надзор. Как правило, эти субъекты публичного управления создаются государством в целях:

- проведения государственной политики;

- предоставления государственных услуг;

- управления государственным имуществом;

- обеспечения модернизации и инновационного развития экономики;

- осуществления контрольных, управленческих и иных общественно полезных функций и полномочий в отдельных сферах и отраслях экономики;

- реализации особо важных проектов и государственных программ, в том числе по социально-экономическому развитию регионов.

K подобным субъектам относятся: унитарные юридические лица в форме публичноправовых компаний, государственные корпорации: Российская корпорация нанотехнологий, государственная корпорация развития «ВЭБ. РФ», государственная корпорация «Агентство по страхованию вкладов», некоторые фонды и государственные учреждения.

Особенностью субъектов системы публичного управления третьего уровня является то, что им передается одно или несколько полномочий публично-правового характера, исполнение которых предполагает осуществление определенного властного воздействия на объекты управления. Но это властное воздействие не является единственным направлением их деятельности, не требует разработки нормативных правовых актов, осуществления надзора, оно лишь малая часть их компетенции. Оставшийся круг полномочий такого субъекта непосредственно связан с консультационной, предпринимательской, финансовой и иными видами деятельности. Эти субъекты производят определенный продукт, участвуют на рынке товаров и услуг. Например, эксплуатация автомобильных дорог и их реконструкция, оказание финансовой поддержки субъектам в сфере промышленности, оказание общественных услуг и другое.

Получается, что субъекты системы публичного управления третьего уровня сочетают в себе признаки и субъекта управления (выполнение полномочия публично-правового характера, стратегической задачи государства), и объекта управления (создание уникальных продуктов, материально-производственная деятельность, культурная деятельность, социальные работы, необходимые для общества и укрепления общественных взаимосвязей). Возникает симбиотический субъект - объект современного публичного управления, и обусловлено его появление реализацией аутсорсинга функций и полномочий от органов исполнительной власти к негосударственным структурам. Плавное перемещение публичных полномочий в бизнес среду и к институтам гражданского общества, отказ от тотального планирования материального производства, децентрализация государственного инициирования на уровень общественного управления позволили наделить объекты управления признаками субъекта публичного управления.

В итоге, значительно видоизменяются формы государственного надзора и контроля, особенно в социально-экономической сфере, так как появляются новые формы взаимодействия государственной власти и социума. Современ- 
ная система государственного управления существует в нестандартных условиях развития общества и мирового устройства, включая междисциплинарные аспекты стратегического планирования экономики и социального благосостояния. И все это создает условия для устранения административных барьеров, уменьшения роли государственного надзора и контроля и усиления значения кооперации между субъектами и объектами государственного управления. Подобная интеграция вызывает интерес всех социальных субъектов в совместном участии в публичном управлении, в получении навыков социальной коммуникации и знаний, в форми- ровании инноваций и технологий и их рациональном использовании без применения жестких форм государственного надзора и контроля. Регуляторная политика государства все больше должна сводиться к предоставлению услуг, оказанию консультативной поддержки, осуществлению стратегического регулирования и координации объектов государственного управления. Это приведет к созданию гибкой, прозрачной и адаптивной среды общественно-социального развития, что станет залогом успешного существования государства и общества в условиях глобальных рисков.

\section{Библиографический список}

1. Концепция открытости федеральных органов исполнительной власти, утв. распоряжением Правительства РФ от 30 января 2014 г. № 93-р.

2. О системе и структуре федеральных органов исполнительной власти: Указ Президента РФ от 9 марта 2004 г. № 314 // Собр. законодательства Рос. Федерации. 2004. № 11. Ст. 945.

3. Об исполнительных органах государственной власти Свердловской области: закон Свердловской области от 24 декабря 1996 г. № 58-О3.

4. О Правительстве и иных органах исполнительной власти Кировской области: закон Кировской области от 26 июля 2001 г. № $10-30$. 